\title{
Trebaju li čudovišta, mutanti i utvare glasati? Monstruozna hrvatska lirika i načelo demokratske jednakosti
}

\begin{abstract}
Vuković Tvrtko, Trebaju li čudovišta, mutanti i utvare glasati? Monstruozna hrvatska lirika i načelo demokratske jednakosti (Should Monsters, Mutants, and Ghosts Vote? Monstrous Croatian Lyric and the Principle of Democratic Equality). "Poznańskie Studia Slawistyczne" 17. Poznań 2019. Publishing House of the Poznań Society for the Advancement of the Arts and Sciences, Adam Mickiewicz University, pp. 285-301. ISSN 2084-3011.
\end{abstract}

The paper starts from the assumption that Croatian modern lyric, from Matoš to Maleš, is haunted by various monsters, phantoms and mutants, and possessed by ghosts. Phantasmal hair speaks, the body changed by illness acquires autonomy, bird-men, space-twins and angels inhabit the humanized world, the dead seek eternity, the turtle measures it's own existence in relation to space and time, and Jesus-fish according to the degree of its own evolutionary transformation, while language cyborgs and hybrid beings are born. The lyric about monsters is itself a monstrous discourse. In this discourse human existence is necessarily contaminated by the abhuman and the parahuman, language includes its own mutations, and the encounter with meaning depends on the ultimate deformation, hybridization and disappearance of meaning. Thus, in the very center of our humanity, in the artistic form that determines the measure of the humanity of our community, questions about what is humane and inhumane, how to determine the boundary between them, and is not the general understanding of humanity always-already determined by one's own inhuman or a-human are raised. Looking at a series of lyric texts, the paper will analyze these relationships and subsequently show their possible political and legal effects. I will refer to theoreticians who read the lyric as a linguistic event and performative type of utterance (J. Culler, P. de Man, B. Johnson, and others) and to thinkers who, to say it simply, perceive the ideas of equality, law and justice as phantasmal, mutated, scandalous or monstrous democracy (G. Agamben, J. Rancière, J. Derrida, J-L. Nancy and others).

KEYwords: Croatian Lyric; performativity; monstrosity; humanity; democracy

\section{Vrlo kratka povijest lirskih čudovišta}

Pretpostavka da je povijest moderne hrvatske lirike također i povijest čudovišta u hrvatskoj znanosti o književnosti ima slabašan analitički 
ugled. No već posve površno poznavanje polja koje se proteže od kraja 19. stoljeća do danas potvrđuje da rasprava o monstruoznosti hrvatske lirike nije ni pretjerana, ni skandalozna premda pretpostavlja stanoviti izgred. Taj se ispad prije svega odnosi na povredu interpretativne i analitičke normalnosti. Naime, pored vojske sablasti, duhova, mutanata, kiborga, anđela, utvara, hibridnih bića, fantoma i živih mrtvaca koja hrvatskom modernom lirikom maršira dulje od stoljeća akademska kritika prolazi gotovo posve bez interesa. Nije nevažno napomenuti da su te „paranormalne“ pojave mahom ugrađene $u$ one lirske opuse i tekstove kojima se gotovo redovito pripisuje nedvojbena estetička i kulturna vrijednost, a time i velik utjecaj prilikom oblikovanja temeljnih svjetonazorskih, etičkih i političkih, riječju općeljudskih načela nacionalne zajednice.

Ako modernost hrvatske lirike započinje Kranjčevićevim djelima ${ }^{1}$, onda je njezina modernizacija neodvojiva od zamišljanja uvida u prekogrobne pojave, davanja mrtvacima, životinjama i objektima moći govora te od uspostave komunikacije s različitim nadnaravnim bićima što svladavaju uobičajeno pojmljene prostorne i vremenske granice. Pjesma Lucida intervala (Kranjčević, 1996, 120) oblikovana je primjerice kao intimni izvještaj mrtvaca iz groba. Taj je Kranjčevićev zombi društveno osviješteni metafizičar koji, prešavši granicu onostranosti, u jednom času komunicira s Budhom. U Utjehi kose, vjerojatno najpoznatijem sonetu Antuna Gustava Matoša $(1976,56)$, čitatelj je suočen s iskazom nežive stvari. Kosa koja tješi neutješnog, međutim, nije jedino Matoševo čudovište. U cinički intoniranoj pjesmi Suvremeni simbol (Matoš, 1976, 12) (književni) kritičar oblikovan je kao jezični mutant nastao mješavinom Darwina, majmuna, satira i Prometeja, a u antologijskoj poemi Mora (Matoš, 1976, 46-55) lirski subjekt ulazi u ulogu umrlog pjesnika koji za sebe tvrdi da više nije čovjek nego živa strvina. Vjerojatno je najpoznatija inačica toga protogotičkog motiva pjesnik iz antologijske Pjesme mrtvog pjesnika Dobriše Cesarića (1996, 55-56). Osim što je stiliziran kao glas iz groba, ima očite vampirske sklonosti. Kako bi povratio vitalizam i mladost, iz vlastite publike crpe životnu energiju. U pjesmama Antuna Branka Šimića

${ }^{1}$ U hrvatskoj znanosti o književnosti Kranjčevićeva se lirika ponekad promatra kao sljedbenica devetnaestostoljetnih poetika, ali joj se počesto pripisuju obilježja koja je svrstavaju u korpus moderne lirike (cf. npr. Frangeš, 1996). 
koje uključuju motiv tijela, na primjer Tijela, Bakterije, Bog i moje tijelo, Umorstvo djeteta, Tijelo i mi, Smrt (Šimić, 1988, 107, 109, 133, 146, 160, 169), fizička je komponenta ljudskosti prikazana ili kao ahumana, otuđena čovječnost ili kao mutirana, čudovišno osamostaljena paraljudskost. Tijelo kao kakva zazorna, istodobno prisna i strana komponenta sebstva tema je i pjesme Čuvajte moj poštovani leš Tina Ujevića $(1966,168-169)^{2}$. Rastakanje postojanosti identiteta Ujevićeva je stalna preokupacija koja je, čini mi se, najizravnije izražena pjesmom Zapis na pragu, u čuvenom stihu: „O ja! o ja! moj drugi i moj treći“ (Ujević, 2005, 244). Ujević međutim ustrajno postavlja i pitanje složenosti odnosa ljudskog i neljudskog. Na primjer: u pjesmi Cvrkutanje srca u pokrajini sanja (Ujević, 2005, 247-248) iskaz donosi čovjek-ptica, u Pobratimstvu lica u svemiru (Ujević, 2005, 256-257) humanoidni se subjekt razdjeljuje i duplira u svom izvanzemaljskom dvojniku, a Vasiona mijena (Ujević, 2006, 116) pjesma je u kojoj je nositelj iskaza sam antropomorfizirani pojam promjene.

U lirici naraštaja oblikovanih nakon Drugog svjetskog rata srodnih je primjera mnogo više. Od pjesnika koji su se javili pedesetih godina 20. stoljeća izdvajam Ivana Slamniga. Njegova se lirska čudovišta pojavljuju na primjer u pjesmama Osjećam, kako se urušujem i Radi se o tom, da zaustavim konja (Slamnig, 1990, 71, 73). Monstruoznost je u njima povezana sa subjektom koji tematizira raspadanje vlastite tjelesnosti. U pjesmi Netko bio (Slamnig, 1990, 92) riječ je o hibridizaciji ljudskog i životinjskog oblika života te o nemogućnosti povlačenja granice među njima. Slamnigovi mutanti su i očovječene životinje; dobar su primjer pjesme Jelen s inhibicijom i Nekad sam bio miš i sve (Slamnig, 1990, 199, 301). Slamnigove sablasti su pak subjekti bez tijela ili rastjelovljeni glasovi. Pojavljuju se, između ostalih, u pjesmama $P o$ zidovima moje sobe plazi nečija sjena i Bukoličnom, trijeznom čitaocu (Slamnig, 1990, 242, 285). Početkom šezdesetih godina 20. stoljeća nastaje možda i najpoznatije čudovište hrvatske suvremene lirike. Kornjača iz zbirke Kornjača i drugi predjeli (1961) Danijela Dragojevića animalni je fenomenolog koji osmišljava vlastitu egzistenciju omjeravajući tijelo i njegovu protežnost o prostor koji svladava kretanjem i pogledom. U cijelosti Dragojevićeva je lirika ispunjena hibridnim, metamorfičkim

\footnotetext{
${ }^{2}$ Upozoravam na odličnu analizu ove Ujevićeve pjesme Ivane Drenjančević (2014).
} 
entitetima nastalima spajanjem materijalnih stvari, životinjskih oblika, ljudskih obilježja i samog jezika. U lirici generacije iz sedamdesetih godina 20. stoljeća slične se mutacije mogu naći u tekstovima Ivana Rogića Nehajeva. U njima se primjerice javljaju: monstruozni hibrid Isusa i ribe u pjesmi Bilješka o Isusu/ribi (Rogić Nehajev, 1999, 312) te u pjesmama iz ciklusa Lakše vježbe iz općenite povijesti ludila iliti postanak slova (Rogić Nehajev, 1999, 157-170) sablasno osamostaljeni dijelovi ljudskog tijela koji se najprije raspadaju u banalnu predmetnost, a potom prelaze u nešto drugo od sebe ne bi li postali najmanja jedinica jezičnog zapisa. No unatoč brojnim pomiješanim oblicima koji se javljaju u lirici Rogića Nehajeva i općenito u lirici pjesnika njegove generacije, sam lirski jezik u sedamdesetima poprima mutantska obilježja: raspada se, generira najčudnije spojeve, odgađa značenje, prikopčava se na vizualne znakove i ne dopušta nikakvu stalnost. Lirski je jezik sedamdesetih godina monstruozna konstrukcija sastavljena od nespojivih dijelova često na prvi pogled bez ikakva smisla i reda, čudovišno otporna na posrebrene interpretacijske metke. Između pjesnika koji su počeli pisati osamdesetih godina 20. stoljeća ističem Delimira Rešickog i njegove dvije zbirke: Gnomi (1985) i Knjiga o anđelima (1997). U prvoj riječ dobivaju demonska bića iz podzemlja, a u drugoj se na granici materijalnog i spiritualnog javljaju eterični anđeli. Početkom devedesetih Anka Žagar objavljuje zbirku Guar rosna životinja (1992). Sam je tekst mjesto „rađanja“ jezičnoga bića: Guar je oblikovan označiteljima, doslovno jest označitelj koji ima i ljudska i životinjska svojstva. Na pragu milenija Krešimir Bagić napisao je dužu pjesmu naslovljenu Hrvatski pjesnik (Bagić, 2001, 5-12). U njoj je hrvatski pjesnik prikazan kao utvarno, bestjelesno stvorenje, ali i kao frankenštajnski lirski hibrid sastavljen od dijelova korpusa drugih hrvatskih pjesnika. Pregled okončavam konstatacijom da u naraštaju pjesnika koji su se javili devedesetih godina 20. i u prvom desetljeću 21. stoljeća srodnih slučajeva ima toliko mnogo da bi njihovo i površno predstavljanje moglo potaknuti efekt sablasnosti koji se javlja $\mathrm{u}$ prisutnosti monstruozno nepregledne građe. 


\section{Na granicama ljudskosti: humano, ahumano i parahumano}

Premda se u domaćoj kulturi doživljava kao diskurs koji ima važnu ulogu u oblikovanju prirode i granica ljudskosti, iz rečenih je primjera očito da je hrvatska moderna lirika izravno upućena na pitanje što znači biti mutant, čudovište, fantom ili utvara. U hrvatskoj se lirici ustrajno artikulira težnja za humanim kao ahumanim, želja da se prijeđe u nešto drugo od ljudskog, da se postane životinja, čudovište, živi mrtvac, biljka, jezični hibrid, anđeo ili kiborg. Drugim riječima, ako je hrvatska moderna lirika diskurs koji nam omogućuje da mislimo o tome što znači biti čovjek, ona to čini tako da nas istodobno suočava s pitanjima što je neljudsko i kako uopće misliti o ne(za)mislivom. Umnoženost ahumanih i parahumanih pojava u modernoj hrvatskoj lirici nedvojbeno, u kulturi utemeljenoj na tradiciji humanizma, izražava žudnju za transgresijom granica ljudskosti, ali izražava i strah pred njezinim padom. Složimo li se s tezom da je rađanje moderne subjektivnosti neodvojivo od izuma nenormalnog (Foucault, 1999), od neke nepregledne drugosti (klasne, rasne, rodne, religiozne, biološke ili vrsne), ta se drugost ne može iz nje izvlastiti bez posljedica. Izvodeći na svjetlo dana neljudsko i čudovišno, neživa, hibridizirana i mutirana bića, to što je na određeni način očita devijacija humanosti, moderna hrvatska lirika suočava nas s utvarnošću koja ustrajno preživljava u središtu najintimnijih pokušaja artikulacije ljudskoga duha. U osnovi kada se u hrvatskoj modernoj lirici pojavljuje čudovišno, ono ukazuje na to što humanistička kultura sama proizvodi, a ne može do kraja kontrolirati. To neljudsko uznemirava ili opovrgava naše ljudske težnje. Način suočavanja s monstrumom - bilo da je riječ o nelagodi, fascinaciji, poricanju, poruzi ili privrženosti - upućuje na odnos koji uspostavljamo prema onome što je s nama samima i našim društvima pošlo krivo. U tom smislu moderna hrvatska lirika šalje upozorenje da je „opsjednutost sablasnim konstitutivni element modernog društvenog života“ te da je dužnost jedne kulture „,suočiti se s aspektima sablasnog“ uključujući „temeljnu promjenu u načinima spoznaje i proizvodnje znanja" (Gordon, 2013, 106). Jedan od najustrajnijih načina kojim se školska čitanja pa i akademska kritika obračunavaju s fantomima što opsjedaju lirske tekstove jest antropomorfizacija. Ona ukazuje na temeljnu nelagodu koju osjećamo u blizini sablasne, izopačene 
drugosti želeći je pod svaku cijenu pripitomiti ili upokojiti. Zato reanimiramo stvari, pojavama koje ga nemaju pridružujemo glas, ne bismo li osjetili prisutnost identiteta koji jamči stabilnost svijeta i značenja (Wolfreys, 2002, xii).

Općenito uzevši, lirska čudovišta funkcioniraju kao semiotički nabijene tekstualne jedinice koje potiču interpretativnu frustraciju, ali omogućavaju doticaj s mehanikom definiranja i oblikovanja normalnosti. Sučeljavajući ga s hibridnim, mutirajućim bićima, kao što su Hrvatski pjesnik iz istoimene Bagićeve pjesme ili Žagaričin Guar, čitatelju se s jedne strane oduzima moć stabilizacije značenja, ali mu se s druge strane skreće pažnja na njihovu konstruiranost i strategije kojima su proizvedena. Smještajući te lirske sablasti u granično područje između ljudskog i neljudskog pažnja se usmjerava na crte razdvajanja čiji je prelazak uvijek rizičan. Iskustvo suočavanja s konceptualiziranim bićima problematizira binarno mišljenje i prisiljava nas da iznova promislimo njime utvrđene pojmove i ideje poput identiteta, kanona ili normalnog. Time se posljedično denaturalizira humanost i pokazuje se da je ljudska priroda, kao uostalom i monstruoznost, proizvod stalne borbe oko diskurzivne konstrukcije i rekonstrukcije moći. No kako je i sama moć sablasna, „može biti nevidljiva, fantastična, [...] očita, dohvatiti vas policijskom palicom, govoriti jezikom vaših misli i žudnja [...], putovati kroz vrijeme i utopiti vas u sadašnjosti [...], ozlijediti vas bez da vas dotakne“" (Gordon, 2013, 103), monstruozno nas u konačnici sučeljava s pitanjem zakona.

\section{Monstruozna demokracija i monstruozna lirika}

Tvrdnja Jacquesa Derridaa da je „sljepilo za nadomjestak zakon“ (Derrida, 1997, 149) tek je na prvi pogled nepoveziva s njegovim kasnijim tekstovima o sablasnosti pravde i demokracije. Nadomjestak je opasan za zakon jer je čudovišno otporan na prisilu sustava, konceptualizacije i hijerarhije. U svojim kasnijim radovima, posebno u onima o politici, pravu, zakonu, jednakosti, Derrida je uvodio figure sablasnosti i monstruoznosti. Njima je nastojao predočiti ,iskustvo nemogućeg“ (Derrida, 1992, 15) i ,područje neodlučivosti“ (Derrida, 1992, 24) demokracije (što je također pripisivao učincima književnosti, točnije literarnosti). Demokracija 
je sablasna i monstruozna jer uključuje mogućnost budućnosti koja se ne može predvidjeti na temelju postojećih, poznatih i ozakonjenih znanja $\mathrm{i}$ iskustava. Kao avet i demokracija je uvijek nadolazeća, ali nikada prisutna kao vlastita realizacija. Njezina se utvarnost ne može uobličiti javnim zakonima ili političkim poretkom, njezino je vrijeme čudovišno jer je uvijek izglobljeno iz tijeka normirane povijesti. Demokracija i pravda su neprestano otvorene, kao sablasti uvijek su drugdje, kao mutanti uvijek su nešto drugo od sebe. Iz njih proizlazi radikalna politika koja ustraje na nemogućnosti politike identiteta, na politici nemogućeg identiteta, čudovišnog, sablasnog, migrirajućeg, rizičnog i nepostojanog u identitetu. Otvaranje vrata apsolutnoj drugosti, tom opasnom nadomjestku, jest otvaranje vrata pravdi i radikalnoj odgovornosti za njezinu čudovišnost. Nenormalnost i sablasnost dakle postavljaju politička pitanja: što znači postojati, biti dio zajednice, uopće što znači biti vidljiv, kakva je naša odgovornost za nemoguću odluku o pravednom djelovanju te kako će svijet u budućnosti izgledati s obzirom na naš odnos prema avetima, monstrumima i mutantima? Biti političan prema Derridau znači prigrliti opasnost nadomjestka, prepustiti se da nas vodi njegova fantomska monstruoznost u neprekidnoj težnji dosezanja (nesigurnosti) pravde i (nemogućnost) jednakosti (Derrida, 2002) $)^{3}$.

U izglobljenosti, singularnosti, otvorenosti i neuračunljivosti (u ludom, onom na što se ne može računati, s čim se ne može kalkulirati) čudovišnog ili sablasnog monstruozna lirika ne ostvaruje tek fiktivni prikaz neke zamišljene povijesne stvarnosti. Ona je ,,događaj prije negoli je reprezentacija nekog događaja“(Culler, 2015, 35), obraćanje koje ima obilježje čina diskurzivne kreacije, pravi apostrofički diskurs.

Poseban je učinak apostrofičkog obraćanja pretpostaviti svijet u kojemu se može za-

${ }^{3}$ Slične težnje Jacques Rancière oblikuje u studiji Mržnja demokracije (2008) zalažući se za oslobađanje skandala demokracije, onoga što ne pripada ni jednom poretku vlasti, skandaloznog izgreda u sustavu raspodijeljenih i utvrđenih uloga. Na drugom mjestu demokraciju naziva „kritičkim oruđem, polemičkim udarnim ovnom“ (Rancière, 2012, 78), čija moć može uzdrmati oligarhije. Jean-Luc Nancy naglašava da je domokracija ,zazivanje mutacije u odnosu čovjeka prema vlastitu kraju ili prema sebi kao 'biću kraja'“. Demokracija je „,zazivanje ljudskosti koja sebe izlaže odsutnosti nekog smislenog kraja“" (Rancière, 2012, 74-75). Zbog toga demokracija nema utemljenje u ideji humanosti, ona je prije izlaganje humanosti radikalnoj stalnoj mutaciji. 
misliti da širi raspon entiteta izvodi djelatne činove opirući se našim uobičajenim pretpostavkama o tome što može, a što ne može djelovati, eksperimentirajući s prevladavajućim ideološkim pregradama koje odvajaju ljudske čimbenike od svega ostaloga (Culler, 2015, 242).

Monstruozna je lirika stoga imanentno društvena i politična jer je njezina snaga u tome da „omogući da se nešto dogodi“ (Culler, 2015, 240). „Trop apostrofe [...], čini se, prije nas uvodi u socijalnu situaciju nego što nas iz nje izvlači“" (Culler, 2015, 221). Riječ je u konačnici o jezičnom događaju koji ima moć na inovativan način organizirati iskustvo, preokrenuti samorazumljivo shvaćanje stvarnosti, osporiti ili dovesti u pitanje uvriježenu raspodjelu uloga i ustaljene modele ophođenja te na scenu svijeta izvesti nepostojeće entitete i samom nepostojećem svijetu udahnuti život. Monstruozna je lirika usklađena sa shvaćanjem političnosti lirike Jacquesa Rancièrea; ima mogućnosti da „obustavi normalne koordinate osjetilnog iskustva“" (Rancière, 2009, 25). Ona na scenu svijeta postavlja nove subjekte i objekte, čini vidljivim ono što je inače nevidljivo, u osjetilnom području zbilje reorganizira na samorazumljiv način raspoređene funkcije (Rancière, 2009, 24-25). Postoji li kakav demokratski potencijal monstruozne lirike, on je u ludilu njezine literarnosti.

\section{Tadijanovićeva čudovišta: majka-smrt i živi mrtvac}

U Tadijanovićevoj pjesmi Zemlja me zove (Tadijanović, 2005, 159) osjećaji strepnje i žala stapaju se s neodredivim osjećajem morbidne privlačnosti prema smrti:

Zemlja me zove, zemlja me zove: moja mati.

Otvara mi srdačno vrata, crna i glomazna,

I čeka da uđem u odaju njenu jednostavnu,

U odaju tihu i bez sunca.

Majka me zove: - Dođi, lezi, usni!

Pokrit ću te lakim pokrivačem,

Pokrit ću te lišćem žutim, lišćem svenutim!

Crvi zemlje, moje matere,

Dugo će se mnome naslađivati:

Bogata će biti gozba u lijesu mojemu! 
Vezi mi, zemljo, vezi od trave mekani sag

I pokrij me njime umorna

Kad snivao budem između crvi.

Nada mnom će, u vjekove, drhtati zvijezda sumorna.

Ima li se u vidu da je zemlja metonimijski povezana s grobnim mjestom i propadanjem tijela, a da je na primjer u pjesmi Bacam srce pod tuđa stopala (Tadijanović, 2005, 178) grobljanski, gotički ambijent doveden u izravnu vezu s toponimom Rastušja, rodnim selom pjesnika, nije pogrešno ustvrditi da zemlja zapravo upućuje na zemlju rodne grude, zavičaja, dakle ono prisno, poznato i voljeno. Taj dojam osnažuje i činjenica da se zemlja više puta katahrestički određuje kao mati, majka, mater, a motiv majke u cijelu autorovu opusu funkcionira kao signal nježnosti, utočišta, blagosti ili svetosti. Neproturječan je primjer za to antologijska pjesma Dugo u noć, u zimsku bijelu noć (Tadijanović, 2005, 170) ${ }^{4}$.

Zemlja me zove pjesma je o prolaznosti ljudske egzistencije. Konačnosti tijela izgrizenog u gozbi crva supostavljena je u zadnjem stihu vječnost zvjezdanog sjaja, ili barem dugovječnost univerzuma prema kojoj je kratkotrajnost čovjekova života bezvrijedno ništavna. No u pjesmi ne privlači pažnju i ne zapanjuje u tolikoj mjeri upečatljiva slika ljudske neznatnosti i bespomoćnosti pred nužnošću umiranja ili izravna brutalnost stihova koji dočaravaju prizor crvljiva i rastočena leša. U najvećoj mjeri zapravo začuđuje sposobnost lirskog teksta da nešto tako odbojno, strano, nasilno i krajnje nelagodno kao što je smrt, pomisao na raspadanje vlastita trupla i slično prikaže kao nešto prisno, poznato, obično, jednostavno ili čak blago. Tu u registru udomaćena pogleda na vidjelo izbija tuđinsko koje je trebalo zauvijek ostati pokopano. Riječ je o iščašenom retoričkom zglobu motiva zemlje i majke, ili bi se trebalo pisati zemljemajke, koji proizvodi učinak zazornog u onom pogledu u kojem ga je najprije predstavio Sigmund Freud (2003).

Očevidno je da je u pjesmi sljubljivanje motiva zemlje i majke potaknuto postojećim sintagmatskim sklopovima ,zemlja majka“, „mati zemlja“, ,rodna gruda“, kojima je u korijenu drevno mitološko personificiranje plodnosti i rađanja. No intonacija lirskog iskaza, upotreba pjesničkih slika i figura te funkcioniranje motiva majke na razini Tadijanovićeva opusa osnažuju dojam da zemlja nije samo zemlja ili točnije da majka

\footnotetext{
${ }^{4}$ Usporedi odličnu analizu te pjesme Josipa Užarevića (2007).
} 
nije samo katahreza zemlje. U pjesmi se dakle osjećaj zazornosti pojavljuje otprilike na ovaj način: zemlja upućuje poziv, ta zemlja je i mati koja srdačno doziva, majka inače zaštićuje i voli, ona je blaga i dobrohotna, obično je svjetlo i toplina, ali tu je hladna raka bez sunca, poziva da se legne u zemlju, drugim riječima da se umre, zemlja pak kao i majka privija u zagrljaj, njezin pokrov je lak kao i majčino brižno ušuškavanje, no crvi zemlje su i crvi matere, mater proždire tijelo kao i zemlja, gozba u lijesu je i njezina gozba. U toj monstruoznoj vezi zazorno nije ono što se obično smatra čudnim ili jezivim, nego ono što je prije svega spojivo s dojmom da se tu nešto otprije poznato i prisno pojavilo u nepoznatom i uznemirujućem obliku. Dobroćudno lice majke neodvojivo je od prizora u kojem primjerice crv prolazi kroz oko mrtvaca. U stihu „Majka me zove: - Dođi, lezi, usni!“ čitatelj ne može posve jasno razlučiti tko govori. Tople i brižne majčine riječi tu su doslovno stavljene u usta smrti, ali tako da majku i smrt više nije moguće razdvojiti. Prema Freudu zazorno je ono što prekoračuje granice racionalnog iskustva, očuđuje ono na što smo navikli, zdravorazumsko mišljenje izvrgava ruglu. U zazornom se pojavljuje element koji ima snagu stabilnost uređena svijeta i sigurnost ustrojenih identiteta poljuljati do temelja. Zazorno tako dovodi u pitanje nastojanja da se ideje poput sebstva ili egzistencije čvrsto teorijski konceptualiziraju.

Zbog toga ne bi trebalo izgubiti iz vida da je središnji retorički postupak ove pjesme općenito uzevši antropomorfizacija ili nešto preciznije prozopopeja. U pjesmi u jednom času zemlja, odnosno smrt, progovaraju jezikom majke: „dođi, lezi, usni“. Kao što sam ranije napomenuo, u tom iskazu nije moguće jednoznačno povući crtu razdvajanja između navedenih entiteta. Djelovanje prozopopeje zazorno je jer nas tjera da se suočimo s tom nemogućnošću i da je na koncu konca prihvatimo. Prije svega prozopopeja „sprječava da se pjesma na zadovoljavajući način čita kao fikcionalna reprezentacija govornog čina stvarnoga svijeta“" (Culler, 2015, 19). De Man je upozorio da je prozopopeja ,vizualni oblik onoga što nema čulnu egzistenciju: halucinacija. Učiniti nevidljivo vidljivim je zazorno“ (De Man, 1981, 34). Time on zapravo tvrdi da je neka zamisliva stabilna jezgra značenja lirske pjesme zapravo i sama već figura. Pokušamo li pjesmu Zemlja me zove tumačiti kao prikaz nemira ili tjeskobe povezane sa smrću, ispuštamo iz vida da je taj prikaz upleten u kompliciranu retoričku aktivnost i da možda zato u većoj mjeri odgađa ono što nastoji uprizoriti. 
Drugim riječima, djelovanje prozopopeje je zazorno jer „dokida razliku između referencije i označivanja na čemu počivaju svi semiotički sustavi““ (De Man, 1981, 34). Zemlja me zove poništava mogućnost da ono što je nereferencijalno i u osnovi neobjašnjivo, a to je činjenica da smrt govori, dobije „semantičko određenje“ ili da se shvati kao „vizionarska referencija racionalnog konteksta“ (De Man, 1981, 34). Budući da je prozopopeja „trop obraćanja, sama figura čitatelja i čitanja“ (De Man, 1981: 31), njezino se djelovanje ne može zanemariti prilikom uspostave značenja. Pokuša li halucinatorni spoj živog i neživog, zemljemajke čitatelj racionalno prevladati, on će to učiniti tako što će toj najčudnijoj stvari dati poznato lice. No time se neće osloboditi halucinacije jer je njegov čin također halucinatorna figuracija figure. Treba stoga imati na pameti kako je ono tumačenje Tadijanoviće pjesme koje previđa prozopopeju upravo povratni upis prozopopeje opterećen različitim nakanama i interesima tumača. Nedvosmisleno analitički objasniti jezik smrti, govor zemlje, postupak je srodan onome kojim se u pjesmi smrti pridružio majčin glas ili zemlji njezino lice. Tadijanovićeva pjesma na taj način skreće pažnju na činjenicu da ni jedna manipulacija drugošću, njezino upokojenje zakonom interpretacije nije neutralno, neovisno i lišeno nasilja i mistifikacije.

Prozopopeja ovdje dakle upućuje na problem koji se javlja kada se u pravilu semantički nestabilno i neodredivo tropološko kolebanje pokušava stabilizirati. Zemlja me zove lirski je događaj koji provocira čitateljevu pažnju, budi njegov nemir ili ga potiče na razmišljanje jer govor smrti i zagrljaj zemlje nije moguće svesti na neko konačno određenje. Taj lirski tekst u manjoj mjeri govori o strahu od smrti, njegovu ublažavanju ili o morbidnoj sklonosti lijeganju u lijes, a u većoj mjeri potiče učinak zazornog tako što aktivira krajnje nesuglasje koje posljedično poništava pokušaj neproblematičnog povezivanja iskaza i referenta. Zemljamajka, smrtmajka - to su koncepti, točnije ne-koncepti, koji uzdrmavaju ideju konceptualizacije. Oni nukaju na promišljanje: kako uopće ustrojiti stvarnost, kako shvatiti vlastito postojanje i uopće što se događa prilikom uspostave osiguranih značenja? Želi li čitatelj semantičkoj bezdanosti pjesme Zemlja me zove pridružiti kakav smisleni temelj, to može učiniti samo po cijenu sljepila za činjenicu da je njegovo čitanje upravo učinak tropoloških preobrazbi koje pjesma ne prestaje stavljati u optjecaj. Na taj način ona ukazuje na nužnu opreznost prilikom raščinjavanja svake iole složenije retoričke 
kompozicije. Na kraju krajeva, ona poučava barem dvije važne lekcije. Prvo: jednostrano, pojednostavljeno i u navike uljuljkano shvaćanje domaćeg i poznatog može dovesti do nimalo bezazlenih etičkih i političkih odluka poput olakog odbacivanja naoko opasnog i stranog. Drugo: domaće i poznato, ono što smo naučeni doživljavati kao prirodno, neupitno i samo naše, nipošto nije lišeno utjecaja monstruoznog, tuđinskog i izopačenog.

Jedna od češćih formi zazornog jest podvostručavanje. U pjesmi Zemlja me zove smrt se takoreći dvostruko podvostručila najprije u personificiranoj zemlji pa u liku sablasne zemljemajke. I na taj je način još jednom zauvijek pokopana sigurnost u stabilnost značenja. Množe se čudna pitanja: je li smrt ljudska ili neljudska, pripada li iskustvu ili ne pripada i je li dio čovjekova života? Prizivam kao mogući odgovor Tadijanovićevu pjesmu Mrtav (Tadijanović, 2005, 218) u kojoj se pojavljuje figura živog mrtvaca ili utvare:

Kapaju li suze na moje mrtvo srce,

Suze mile djevojke?

U šumi, na šušnju, kod zapada sunca,

Ležim... umro. Obasjan.

Gdje je razlupana harfa?

Klokotanje blistavog vrela

Ulazi u mrtvo srce.

Na grani se ljulja kos,

Visoko, sam;

Ide mala noć. A sveti Petar uzima

Iza uha olovku

I prstom zove moju baku:

Nagnuvši se gledaju

Kroz tužno lišće

Srce pod stablima

Mrtvo. Moje srce?

Al ne čuju klokotanje,

Jer su daleko... iza večernjeg oblaka.

U šumi, u tišini, u strahu, kapaju suze

Lude djevojke:

Ide mala noć.

Mrtvo srce sipi.

Tu je očito riječ o poigravanju s idejom da ljudsko uvijek već uključuje neljudsko i fantomsko čime se, tvrdim, osporava logika homogenosti identiteta. Semantičku nit pjesme nije lako rekonstruirati. Tadijanovićev 
zombi ima naoko ljudske preokupacije i probleme: misli na milu djevojku, promatra okolnu šumu, traži harfu, spominje svoju baku i svetog Petra, na zakučast način višekratno tematizira vlastito srce tako da se ne može znati je li tu ono sinegdoha ljubavnika, katahreza zaljubljenosti ili naprosto tjelesni organ. Pitanje je dakle kako komunicirati s tom posvema neproničnom pjesničkom slikom. Odgovor je također u nekom smislu sablastan: mrtvac je utvara koja komunikaciju s lirskim tekstom i sam lirski tekst čini ukletima. Kada se gleda sablast, vidi se ono što se ne može vidjeti; kada se čita pjesma Mrtav, čita se ono što se ne može čitati. Čitanje ove pjesme opsjeda utvara nečitljivosti. Mogući odnos čitatelja prema toj radikalnoj tuđosti može biti ili otvaranje vrata sablasti ili njezino upokojenje. Nečitljivo je opasno, ali uzbudljivo. Pustiti da u čitanje upadne nečitljivo rizičan je čin koji može biti i zabavan, i spoznajno produktivan, i kritički poticajan. Opsesivno ne dopuštati da se to dogodi krut je način da naše ovjereno čitanje zaštitimo od neugodnih pitanja koja fantomi znaju postavljati: zašto je baš tu utvrđena granica, zašto se u tome vidi isključivo to, a ne i ovo, zašto se u jedno ne ubraja i ono drugo i slična?

\section{Politika krivosti i monstruozna lirska demokracija}

Susret s monstruoznom lirikom pred čitatelja nedvojbeno postavlja nekolicinu izazova: kako stupiti u odnos s deformacijom humanosti, misliti o granici mislivog i nemislivog te kako na tren barem prihvatiti obustavu normalnosti. U određenom smislu nagovara ga se da zauzme bilo kakav stav prema onome što je u uobičajenim predodžbama o ljudskosti, mišljenju, zajedništvu ili jednakosti pošlo krivo.

Za kraj ću izložene teze i čitanja monstruozne lirike pokušati povezati s Rancièreovom političkom mišlju i posebno s njegovim pojmom krivost (le tort $)^{5}$. Ukratko, Rancièreovo shvaćanje politike neodvojivo je od onoga

${ }^{5} \mathrm{U}$ francuskom le tort ima više značenja: imati krivo, biti u krivu, krivda ili nepravda, ali i učiniti nešto pogrešno, izazvati štetu, tako da bi prijevod termina mogao biti i štetnost ili pogrešnost. Odlučio sam se za krivost jer u najvećoj mjeri odgovara izvornom značenju koje dolazi iz latinskog tortum, odnosno tortus, a u smislu: iskrivljen, izobličen, izvijen (http:// www.cnrtl.fr/etymologie/tort, 4.02.2019). Sukladno je to ovdje predloženom pojmu monstruoznog ili sablasnog: sve što je u formiranom prostoru deformirano. 
što on naziva policijom ${ }^{6}$. Policija je sistem raspoređivanja subjekata u socijalnom poretku: smještanje tijela, dodjeljivanje uloga, određivanje načina na koji netko nešto čini, govori ili se ponaša. Onaj tko nema mjesto u sustavu policije nije naprosto marginaliziran, nego je za njega nerazumljiv, doslovno nevidljiv. Rancière ne staje u obranu onoga što se obično naziva demokratskim poretkom. On naime smatra da mi i dalje živimo u državama oligarhijskog poretka jer oligarhijske poretke obilježavaju hijerarhija i dominacija koje naturaliziraju nejednakost. Ono što njega zanima skandal je demokracije koji se ne odnosi na nešto skandalozno što se događa s našim demokracijama ili na neki skandalozni dio poput korumpirane birokracije koja iznevjerava ideju demokracije. Skandal je suština demokracije. U demokracijama je skandalozno to što se vladavina ne poziva ni na jedno prirodno načelo nejednakosti poput jaki - slabi ili inteligentni - neinteligentni. Na taj su način ustrojene oligarhije i one nisu skandalozne, nego su banalne. Demokracija je skandalozna jer nije režim, forma društva ili sustav političkih institucija. U doslovnom smislu Rancière tvrdi da ne postoji demokratska vladavina i vlast. Vlast je uvijek oligarhijska. Reprezentacijska je demokracija stoga oksimoron i oligarhijska forma jer se skandal demokracije ne može reprezentirati. Skandal je demokracije povezan s politikom.

Politika je prema Rancièreu ono što stoji nasuprot policijskom poretku. Politika se pojavljuje kada logiku policijskog poretka, dominacije, ospori posve drukčija logika, logika jednakosti. Demokracija dakle uzdrmava oligarhiju; ona nije zamjena za oligarhiju, nego je esencija politike. Politika i demokracija suprotstavljene su policiji i oligarhiji. Oligarhiju ne možemo zamijeniti demokracijom jer je demokracija ono što se u oligarhijama pojavljuje kao paradoksalna sila. Rancière se slaže da se sve političke teorije temelje manje-više na ideji da bi ljudi trebali u načelu biti jednaki. No prava demokratska politika utjelovljena je u činu koji izranja iz pretpostavke jednakosti. Tu nije riječ o davanju jednakosti nejednakima, što je obilježje demokratskih režima, nego o djelovanju na temelju pretpostavke da svi doista jesu jednaki. Jednakost je dakle vidljiva u praksama koje ga u društvo ugrađuju. Nije isto tražiti da se nekome prizna status jednakosti

${ }^{6} \mathrm{Ne}$ navede li se drukčije, prilikom prikaza Rancièreove političke misli koristio sam se knjigama iz popisa literature (Rancièr, 1995; 1999; 2008; 2009). 
i zahtijevati to djelovanjem iz pozicije jednakosti. U prvom slučaju moć imaju oni koji jednakost raspodjeljuju, a u drugom sami sudionici čina. U svakom demokratskom političkom pokretu postoji konflikt između onih koji djeluju u ime jednakosti i samog socijalnog poretka. To Rancière naziva „neslaganje“ (une mésentente). „Neslaganje“ je situacija u kojoj policijski poredak ne može uopće čuti nečiji glas kao govor ili prepoznati ga kao stav. Iako se danas misli da svi imaju pravo glasa, da svi mogu izreći svoj stav, elite obično smatraju da narod nema što vrijedno reći. Zato se demokratska politika jednakosti mora suočiti s opisanim oblikom „neslaganja“. Kada policijski poredak ne može prepoznati nečiju jednakost jer ne čuje njegov glas kao izricanje stava, Rancière to naziva „krivošću“. Prava demokratska politika ukazuje na „krivost“ tako što jednakost izvodi na scenu policijskog poretka. Esencija jednakosti nije povezivanje ili objedinjavanje koliko deklasifikacija ili opovrgavanje navodne prirodnosti poretka. Djelovanjem na temelju jednakosti neka „krivost“ izranja na mjestu na kojem prije nije postojalo ništa ili je doslovno postojalo ništa. Na taj način društveno polje doživljava rekonfiguraciju. Oni koji u njemu sudjeluju, prisiljeni su vidjeti ono što je do tada bilo nevidljivo. Prava demokratska politika dakle nema ništa s tim što je narodu dano ili što narod može očekivati. Ona je ono što netko čini pod pretpostavkom jednakosti u policijskom poretku. Drugim riječima, nejednaki djeluju kao da su jednaki i na taj način policijski poredak prisiljavaju na preoblikovanje shvaćanja i prihvaćanja mogućih činova i političkih subjekata.

Raspodjela osjetilnog (partage du sensible), prema Rancièreu, temelji se na percepciji koja se oslanja na objekte navodno prirodno predodređene da budu vidljivi. Prava demokratska politika javlja se kada kakav nevidljivi element društva, neka društvena „krivost“, propituje vladajući poredak. Zadatak je politike dakle estetički: rekonfigurirati uvjete senzorne percepcije tako da se između uvriježenih značenja i percepcije poruše granice i da nevidljivo postane vidljivo. Zato su estetika i politika u stalnoj vezi: osjetilnost i perceptibilnost preduvjeti su vidljivosti subjekata, njihove moći govora, zauzimanja prostora. Organizacija vidljivog i nevidljivog u društvu neodvojiva je od načela osjetilne organizacije koja je u temelju estetike. Rancière stalno istražuje liniju koja razdvaja jednako od nejednakog, onoga tko zna od onoga tko ne zna. Političko je djelovanje estetičko jer ono preoblikuje društvenu osjetilnost tako što u nju izravno uključuje 
„krivost“". Monstruozna lirika ima mogućnost djelovati demokratično i politički ne zbog ideja koje prenosi, nego zbog toga što aktivno sudjeluje u raspodjeli osjetilnog istodobno u poljima društva i estetike. U položaj vidljivog i razumljivog ona postavlja „krive“, nevidljive i nerazumljive, subjekte, teme i ideje. Budući da se mogu razumjeti i vidjeti samo kao „krivost", oni imaju potencijal za rekonfiguriraciju postojeće hijerarhije znanja i moći u književnom, kulturnom, a posljedično, putujući s čitateljima, i u društvenom polju ${ }^{7}$. Na određeni način nijemost subjekata tu paradoksalno postaje njihov glas. Izborivši se za to da čudovišta, mutanti i utvare dobiju mjesto s kojega će uputiti svoj glas, monstruozna lirika i njezina monstruozna demokratska politika djeluju tako da svaki glas, a ponajviše glas ušutkanog, nijemog, nevidljivog i ,krivog“ moramo čuti. Tom bi glasu napokon i akademska i društvena kritika, ako se zalažu za pravu demokratku politiku, morale otvoriti glasačko mjesto. Morale bi rasporiti okoštalu društvenu i kulturnu osjetilnost tako da (se) iz te pukotine „krivost“ može glasati.

\section{Literatura}

Bagić, K. (2001). Jezik za svaku udaljenost. Zagreb: Naklada MD.

Centre national de ressources textuellles et lexicales. http://www.cnrtl.fr/etymologie/ tort. 4.02.2019.

Cesarić, D. (1996). Izabrane pjesme. Prir. V. Pavletić. Zagreb: Matica.

Culler, J. (2015). Theory of the Lyric. Cambridge - London: Harvard University Press.

De Man, P. (1981). Hypogram and Inscription: Michael Riffaterre's Poetics of Reading. „Diacritics“" no. 4, str. 17-35.

Derrida, J. (1992). Force of Law: The Mystical Foundation of Authority. U: Decon-

\footnotetext{
${ }^{7}$ Posve sam svjestan mogućeg prigovora da je teško utvrditi razmjere subverzivnosti nekog književnoga teksta. Izvjesnije je da njegovo djelovanje nije strateški politički usmjereno, nego je ponajprije nepredvidivo i složeno, a rijetko je kada po društvene poretke opasno i podrivačko. Smatram ipak da monstruozna lirika može poslužiti kao platforma za promišljanje našeg shvaćanja jednakog, normalnog i etičnog te za pokretanje važnih promjena u našem odnosu prema drugosti i različitosti. Trebalo bi provesti sveobuhvatnije istraživanje koje bi analiziralo načine na koje taj tip lirskog teksta djeluje na promjenu utvrđenih stavova čitatelja i posljedično na njihovu percepciju mogućnosti društvenih promjena. Recenzentima zahvaljujem na dobronamjernim upozorenjima vezanim za rečene probleme.
} 
struction and the Possibility of Justice. Eds D. Cornell, M. Rosenfeld, D. Grey Carlson. London: Routledge, str. 1-67.

Derrida, J. (1997). Of Grammatology. Baltimore: The Johns Hopkins University Press. Derrida, J. (2002). Sablasti Marxa. Stanje duga, rad tugovanja i nova internacionala. Zagreb: Hrvatska sveučilišna naklada.

Dragojević, D. (1961). Kornjača i drugi predjeli. Split: Matica hrvatska.

Drenjančević, I. (2014). Nemoguć zahtjev: očuvati leš teksta. „Umjetnost riječi“ br. I, str. 1-16.

Foucault, M. (1999). Les anormaux. Paris: Gallimard - Le Seuil.

Frangeš, I. (1996). Silvije Strahimir Kranjčević. U: Silvije Strahimir Kranjčević. Izabrana djela. Zagreb: Matica hrvatska, str. 13-40.

Freud, S. (2003). The Uncanny. New York: Penguin Books.

Gordon, A. F. (2013). Her shape and his hand. U: The Spectralities Reader. Ghost and Hunting in Contemporary Cultural Theory. Eds M. del Pilar Blanco i E. Peeren. London: Bloomsbury, str. 103-129.

Kranjčević, S. S. (1996). Izabrana djela. Prir. I. Frangeš. Zagreb: Matica hrvatska.

Matoš, A. G. (1976). Sabrana djela. Pjesme. Pečalba. Ur. D. Tadijanović. Zagreb: JAZU-Sveučilišna naklada Liber.

Nancy, J.-L. (2012). Finite and Infinite democracy. U: Democracy in the What State? New York: Columbia University Press, str. 58-75.

Rancière, J. (1995). La Mesentente: Politique et philosophie. Paris: Editions Galilee.

Rancière, J. (1999). Disagreement. Politics and Philosphy. Minneapolis - London: University of Minnesota Press.

Rancière, J. (2008). Mržnja demokracije. Zagreb: Ljevak.

Rancière, J. (2009). Aesthetics and its Discontents. Cambridge: Polity Press.

Rancière, J. (2012). Democracies Against Democracy. U: Democracy in the What State? New York: Columbia University Press, str. 76-81.

Rešicki, D. (1985). Gnomi. Zagreb: CDD SSOH.

Rogić Nehajev, I. (1999). Sredozemlje sedmi put. Prir. B. Maleš. Zagreb: Lunapark.

Slamnig, I. (1990). Sabrane pjesme. Zagreb: GZH.

Šimić, A. (1988). Djela, I. Sarajevo - Zagreb: Svjetlost - August Cesarec.

Tadijanović, D. (2005). Sabrane pjesme. Zagreb: Školska knjiga.

Ujević, T. (1966). Sabrana djela XV. Zagreb: Znanje.

Ujević, T. (2005). Izbor pjesama I. Prir. A. Stamać. Zagreb: Matica hrvatska.

Ujević, T. (2006). Izbor pjesama II. Prir. A. Stamać. Zagreb: Matica hrvatska.

Užarević, J. (2007). Dugo u noć, u zimsku bijelu noć. U: Zbornik radova o Dragutinu Tadijanoviću. Zagreb: Školska knjiga, str. 208-217.

Wolfreys, J. (2002). Victorian Hauntings. Hempshire: Palgrave.

Žagar, A. (1992). Guar rosna životinja. Zagreb: Hrvatska sveučilišna naklada. 